\title{
Rhinoplasty in the elderly
}

\author{
C Alfano \\ From de Senectute: Age and Health Forum \\ Catanzaro, Italy. 5-7 December 2009
}

Both functional and cosmetic rhinoplasty in the elderly require a different surgical approach due to the morphological and structural changes of the nose that are connected to the aging process.

Such processes determine changes of all anatomical structures that form the aesthetic-functional unit. In particular thinning of the skin envelope becomes apparent with pores dilatation and increased secretion of sebum, in males in particular, subcutaneous tissue involution and thinning of muscle layers with weakening of cartilages. All these involutional anatomical changes that become apparent with the aging process, demand a less aggressive surgical approach with grater respect and attention of the anatomical structures. When compared with the younger patient, the relative structural hypotrophy of the anatomy of the elderly, makes even minor changes and small imperfections become more apparent.

What we mean by elderly patient requires clarification. In the majority of cases a rhinoplasty is carried out on patients between age 18 and 40 .

The fact that a patient should be defined old when he/she reaches a certain age in not axiomatic. A person can feel "old" even when he/she is 35-40 years of age, obviously concealing a certain degree of psychological problems. This fact should induce the surgeon, before operating, to well consider the psychological motivations of the patient who requests this surgical procedure at an advanced age and to consider why he did not request this procedure earlier. On selected cases a psychological consultation can be of great help to better understand the patient and can protect the surgeon from unpleasant litigation.

The most obvious phonotypical consequences of the aging process are represented by nasal tip ptosis and alar cartilages collapse with consequent alteration of the air flow further aggravated by progressive thinning of the mucous layer and relative glandular atrophy.

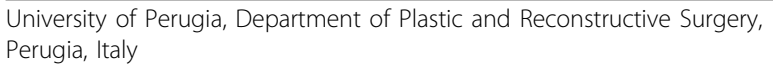

From a cosmetic point of view, the aging of the face determines a reduction of the vertical dimensions of the lower third of the face together with a lengthening of the middle third made even more obvious by the lowering of the tip of the nose and the distraction of the lower lateral cartilages.

We believe that a rhinoplasty is a subtractive operation only being augmentative in selected secondary conditions. It is a tenet of this discipline that in a rhinoplasty what is removed is just as important as what is being left.

We believe that performing a rhinoplasty in the elderly demands consideration of the psychological implications and from a technical standpoint greater care in performing all resections in view of the thinning of tissues and of the underlying anatomical structures.

The main objective of a rhinoplasty in the elderly should be an adequate reorientation and stabilization of the lower lateral cartilages to achieve a positive tip rotation and an adequate projection.

Published: 19 May 2010

doi:10.1186/1471-2318-10-S1-L2

Cite this article as: Alfano: Rhinoplasty in the elderly. BMC Geriatrics 2010 10(Suppl 1):L2.

Submit your next manuscript to BioMed Central and take full advantage of:

- Convenient online submission

- Thorough peer review

- No space constraints or color figure charges

- Immediate publication on acceptance

- Inclusion in PubMed, CAS, Scopus and Google Scholar

- Research which is freely available for redistribution

Submit your manuscript at www.biomedcentral.com/submit 